\title{
Some Population Parameters of the Sardinella maderensis (Lowe, 1838) in the Sombreiro River of Niger Delta, Nigeria
}

\author{
Olaniyi Alaba OLOPADE ${ }^{1 *}$, Henry Eyina DIENYE ${ }^{1}$, Nathanael Akinsafe BAMIDELE ${ }^{2}$ - \\ ${ }^{1}$ Department of Fisheries, Faculty of Agriculture, University of Port Harcourt, Nigeria. \\ ${ }^{2}$ Institute of Food Security, Environmental Resources Agricultural Research Federal University of Agriculture, \\ Abeokuta, Nigeria.
}

*Corresponding Author: olaniyi.olopade@uniport.edu.ng

Received 26 February 2019; Accepted 09 April 2019; Release date 15 September 2019.

How to Cite: Olopade, O.A., Dienye, H.E., \& Bamidele, N.A. (2019). Some population parameters of the Sardinella maderensis (Lowe, 1838) in the Sombreiro River of Niger Delta, Nigeria. Acta Aquatica Turcica, 15(3), 354-364. https://doi.org/10.22392/actaquatr.532284

\begin{abstract}
A study was conducted to estimate the growth and stock characteristics of the Sardinella maderensis (Lowe, 1838) from Sombreiro River of Niger Delta, Nigeria. Results obtained revealed that mean total length and the mean weight of $S$. maderensis ranged between $4.1 \mathrm{~cm}$ to $18.5 \mathrm{~cm}$ and $5 \mathrm{~g}$ to $55.5 \mathrm{~g}$ respectively. The b value of the length-weight relationship was 2.58 thus, the species could be categorized as displaying allometric negative growth and condition factor was very high, it ranged from 3.04 to 4.43 . The estimated von Bertalanffy growth parameters (VBGP) of L $\infty$, growth coefficient (k) and age at zero length $\left(\mathrm{t}_{0}\right)$ were $23.31 \mathrm{~cm}, 0.54$ and $-0.03 /$ year respectively. The species showed year round recruitment patterns having two peak periods during April and July. The total mortality (Z) was 2.74 year- $^{-1}$., the natural mortality rate (M) and fishing mortality (F) were 1.32 and 1.42 respectively. The estimated fishing mortality $(\mathrm{Z}-\mathrm{M}=\mathrm{F})$ stood at 0.518 . The lengthbased index of growth performance ( $\varnothing^{\prime}-$ phi prime) for $S$. maderensis was estimated at 2.46 . The length at first capture $\mathrm{L}_{50}$ was $27.31 \mathrm{~cm}$. The exploitation rate $\left(\mathrm{E}_{\max }\right)$ was 0.421 whereas $\left(\mathrm{E}_{0.1}\right)$ was observed to be 0.355 indicating that that the level of exploitation is already high and to obtain the maximum sustainable yield, the present level of fishing effort should be reduced through appropriate fishing regulation techniques..
\end{abstract}

Keywords: Length- weight relationship, condition factor, population parameters, Sardinella maderensis, Sombreiro River, Nigeria

Sombreiro Nehri'ndeki (Nijer Deltası, Nijerya) Sardinella maderensis'in (Lowe, 1838) Bazı Popülasyon Parametreleri

\section{Özet}

Bu çalışma, Nijerya'daki Nijer Deltası'nın Sombreiro Nehri'ndeki Sardinella maderensis (Lowe, 1838), populasyonlarının bazı büyüme ve stok özelliklerini belirlemek için yapılmıştır. Elde edilen sonuçlar, S. maderensis'in ortalama toplam uzunluk ve ortalama ağırlığının sırasıyla $4,1 \mathrm{~cm}$ ile $18,5 \mathrm{~cm}$ ile $5 \mathrm{~g}$ ile $55,5 \mathrm{~g}$ arasında olduğunu göstermiştir. Uzunluk-ağırlık ilişkisinin b değeri 2,58 olarak tespit edilmiştir, bu nedenle türler, allometrik negatif büyüme gösteriyor şeklinde kategorize edilebilir. Bu türün durum faktörü 3,04 ile 4,43 arasında çok yüksek olarak belirlenmiştir. Tahmini L $\infty$, von Bertalanffy büyüme parametreleri (VBGP), büyüme katsayısı (k) ve sıfır uzunluktaki yaş (t0) sırasıyla 23,31cm, 0.54 ve -0.03 / yıl olarak belirlenmiştir. Türler, Nisan ve Temmuz aylarında iki tepe periyodu olmak üzere yıl boyunca dağılım göstermektedir. Toplam mortalite (Z) 2.74 yıl, doğal ölüm oranı (M) ve balıkçılık ölümleri (F) sırasıyla 1,32 ve 1,42 olarak bulunmuştur. Tahmini balık ölümü (Z-M = F) 0,518 seviyesinde gerçekleşmiştir. $S$. maderensis için uzunluk temelli büyüme performansı endeksi (Ø'- phi prime) 2.46 olarak hesaplanmıştır. İlk yakalama L50'deki uzunluk 7,19 cm olarak bulunmuştur. $\mathrm{E}_{\max }(0,421)$ ve $\mathrm{E}_{0.1}(0,355)$ değerleri türden maksimum verim alınabilmesi için uygun balıkçılık düzenlemeleri ile mevcut avlanma baskısının azaltılması gerektiğini göstermektedir.

Anahtar kelimeler: Uzunluk-ağırlık ilişkisi, durum faktörü, populasyon parametreleri, Sardinella maderensis, Sombreiro Nehri, Nijerya 


\section{INTRODUCTION}

Clupeids are chiefly marine coastal and schooling fishes; some freshwater and anadromous (Gaudant, 1991) widely distributed in the tropical and subtropical region (Riede, 2004) including the entire Mediterranean and the Black sea (Froese and Pauly, 2017). These are small, silvery fishes with fusiform, or strong compressed body. Three genera consisting of six species have been identified in Nigerian freshwaters Adesulu and Sydenham (2007). Sardinella maderensis belonging to family clupidae. S. maderensis resembles Sardinella aurita, but pelvic fin with 1 unbranched and 7 branched rays and no black spot on hind part of gill cover, but a faint gold or black area just behind gill opening (Tous et al., 2015). The species has maturity mean length of $13.4 \mathrm{~cm}$ and common length $25 \mathrm{~cm}$ (Whitehead, 1985).

The population of the $S$. maderensis is declining due to overfishing, with the average size of fish in the catch reducing and as a result, the International Union for Conservation of Nature has rated its conservation status as "vulnerable (Tous et al., 2015). The fish species is considered as one of the most important fishery resources in marine and brackish water in Nigeria because of its abundance in the landings. In Nigeria, S. maderensis accounts for 15,115 tonnes of fish production by species in 2015 (NBS, 2017). In spite of its economic importance, there is paucity of information on population parameters and biology of $S$. maderensis in Nigerian water bodies.

An approach towards conservation and management of the population of this particular fish species demands the generation of information on the stock or population structure. Stock assessment generally aims to estimate the current stock size and its potential for increased in size (de Graaf, 2015). Generally the size of the total stock of a race, species, (or) group of species vary from year to year and from one region of the world to the other. These fluctuations in abundance are caused by natural factors and also by man's activity. The estimation of stock abundance is important in determining the effects of fishing and environmental disturbances as well as in estimating parameters such as length-weight relationships, recruitment variability, mortality and stock status. These information are required for consideration of management measures of the species in the future. As there is currently no knowledge of $S$. maderensis stock structure in the Sombreiro River. Therefore, this study was carried out to estimate population parameters, yield per recruit, biomass and MSY on $S$. maderensis in order to formulate management and conservation policies.

\section{MATERIALS and METHODS}

Sombreiro River system (between latitude $6^{0} 30^{1}$ and $7^{0} 0^{1} \mathrm{E}$, and longitude $4^{0} 12^{1} \mathrm{~N}$ and $60^{0} 17^{1} \mathrm{~N}$ ) is located in Rivers State in the Niger Delta region of Nigeria (Figure 1). It has its source from the Niger River, runs downwards into the Southern tip of the Niger Delta basin and empties into the Atlantic Ocean (Ezekiel et al., 2011). The middle reach of the Sombreiro River is brackish and appears turbid during the raining season. The extent of brackish in this river is between $117-132 \mathrm{~km}^{2}$ Ssentongo et al. (1983) and Nduaguba (1983). Two distinct seasons is usually observed in a year. They include the rainy and dry season. The maximum temperature is between $26-28^{\circ} \mathrm{C}$ and mean annual rainfall is $362.5 \mathrm{~mm}$. The climate presents two distinct seasons; a rainy season (April October) and a dry season, (November - March). 


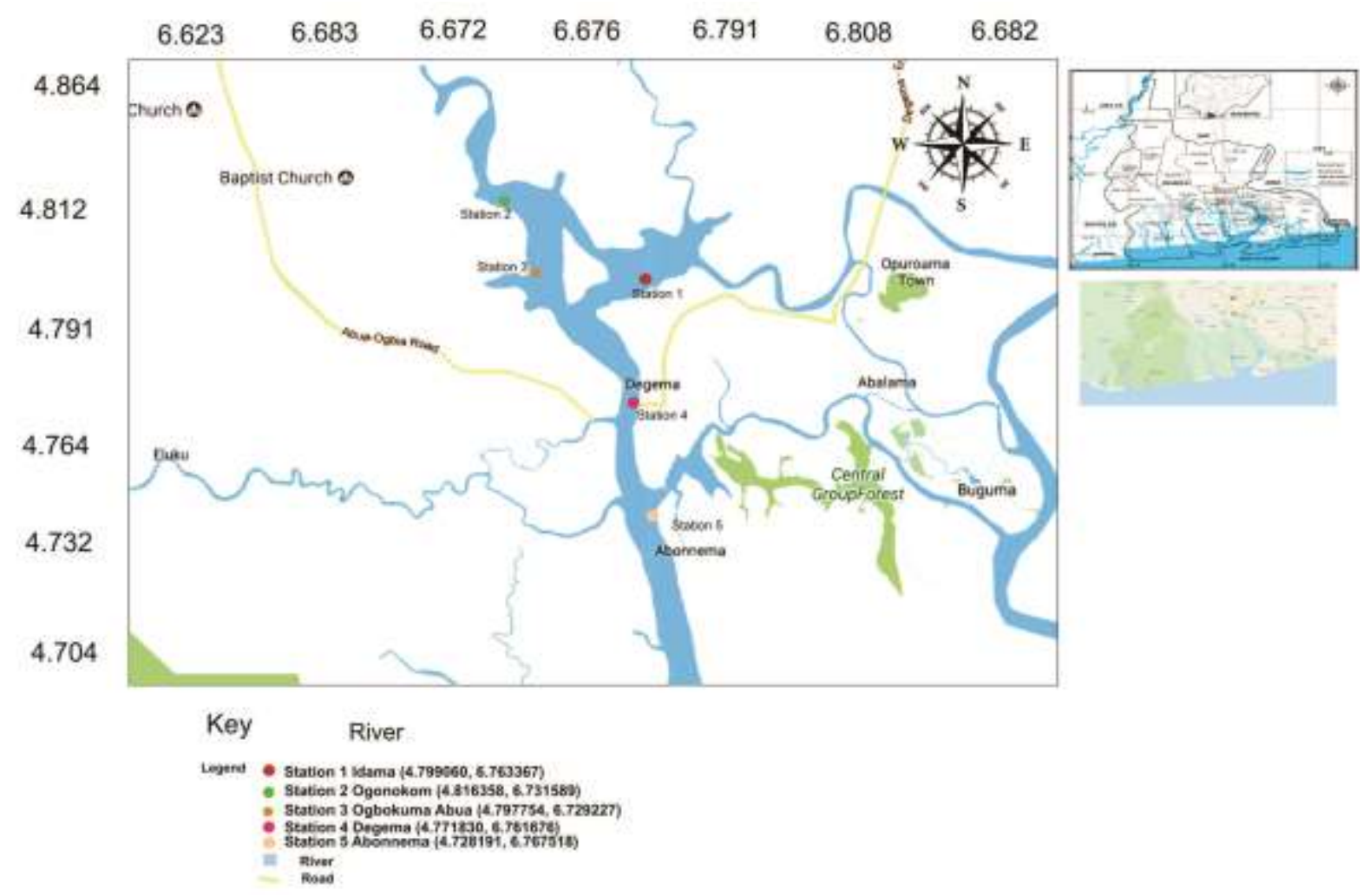

Figure 1. Map of Sombreiro River showing the study area

A total of 531 S. maderensis were collected monthly the period from January to December 2017 at five different stations (Degema, Ogonokomi, Ogbokuma Abua, and Abonnema) within the Sombreiro River.

These sites were chosen because they are the fishing and landing grounds of fishermen. Fishes were identified to species level based on Schneider (1990). Samples were transported to the laboratory for further evaluation. Total Length (TL) and Standard Length (SL) were measured to the nearest 0.01 $\mathrm{cm}$ using digital slide calipers and graduated plastic measuring board and total Body Weight (BW) was weighed by an electronic balance with $0.01 \mathrm{~g}$ accuracy for each individual.

The length/weight relationship of the fish was described by the equation: $\mathrm{W}=\mathrm{axL}^{\mathrm{b}}$, where $\mathrm{W}=$ weight in grams, $\mathrm{L}=$ total length in centimetres, and $\mathrm{a}$ and $\mathrm{b}$ are regression constants. This can be expressed in logarithmic form as $\log \mathrm{W}=\log \mathrm{a}+\mathrm{b}(\log \mathrm{L})$ suggested by Le Cren (1951). Length and weight data were used to calculate the Fulton condition factor, ' $k$ ' from the equation: $k=100 \mathrm{~W} / \mathrm{L}^{3}$, where $\mathrm{W}=$ weight in grams, and $\mathrm{L}=$ length in centimetres.

The growth parameters were estimated by fitting length frequency data into the von Bertalanffy growth function (VBGF) was used to describe the fish growth; $\mathrm{Lt}=\mathrm{L} \infty(1-\exp (-\mathrm{k}(\mathrm{t}-\mathrm{t} 0)))$

where $\mathrm{Lt}$ was the predicted length in the $\mathrm{cm}$ at age $\mathrm{t}, \mathrm{L} \infty$ is the asymptotic length, $\mathrm{K}$ is the growth coefficient and t0 was the hypothetical age at which length of the fish is equal to zero (usually negative), (Haddon, 2011) which can be estimated from the empirical equation of Pauly (1983) as:

$\log 10\left(-\mathrm{t}_{0}\right)=-0.3922-0.275 \log 10 \mathrm{~L} \infty-1.038 \log 10 \mathrm{~K}$

The total mortality coefficient ( $Z$ ) was estimated by using Beverton and Holt's (1956) equation $Z=$ $\mathrm{K}\left((\mathrm{L} \infty-\mathrm{L}-) /\left(\mathrm{L} \infty-\mathrm{L}^{\prime}\right)\right)$ where $\mathrm{Z}$ is the instantaneous total mortality coefficient, $\mathrm{L}$ - is the mean length and $\mathrm{L}^{\prime}$ is the length for which all fish of that length and longer are under full exploitation. Natural mortality coefficient (M) was calculated by using Pauly empirical formula (1980): $\log M=-0.0066-$ $0.279 \log \operatorname{L} \infty+0.6543 \log \mathrm{K}+0.4634 \log \mathrm{T}$; where $\mathrm{T}$ is the annual mean temperature. The fishing mortality coefficient $(\mathrm{F})$ was computed as $\mathrm{F}=\mathrm{Z}-\mathrm{M}$.

The recruitment pattern of the stock was determined by backward projection on the length axis of the set of available length frequency data as described in FiSAT II (Pauly and Caddy, 1985).

Growth performance index (Ø') was calculated by the equation given by Pauly and Munro (1984): $10 \log 2 \log \mathrm{k} \mathrm{L}^{\prime} \infty=+$ 
Probability of capture against mid-length a resultant curve was used to compute the length at first capture $\left(\mathrm{Lc}_{50}\right)$. Length at first maturity $\left(\mathrm{Lm}_{50}\right)$ was estimated as: $\operatorname{Lm}_{50}=(2 * \mathrm{~L} \infty) / 3$ (Hoggarth et al., 2006)

Relative yield per recruit $\left(\mathrm{Y}^{\prime} / \mathrm{R}\right)$ and relative biomass per recruit $\left(\mathrm{B}^{\prime} / \mathrm{R}\right)$ were estimated using the model of Beverton and Holt (1959) as modified by Pauly and Soriano (1986) and incorporated in the FiSAT software.

\section{RESULTS}

\section{Length-weight relationship and condition factor}

As indicated in Table (1), the mean total length and mean weight of $S$. maderensis ranged between $4.1 \mathrm{~cm}$ to $18.5 \mathrm{~cm}$ and $5 \mathrm{~g}$ to $55.5 \mathrm{~g}$ respectively. The weight of the fish strongly correlated with the total length (TL) with $\mathrm{r}^{2}$ value of 0.89 . The $\mathrm{b}$ value of the length-weight relationship was 2.58 thus, species could be categorized as displaying allometric negative growth. The value of $(\mathrm{K})$ of the under study species was very high, it ranged from 0.52 to 7.82 and with mean value of $4.43 \pm 0.07$ (Table 1).

Table 1. Length-weight relationship and condition factor of $S$. maderensis from Sombreiro River

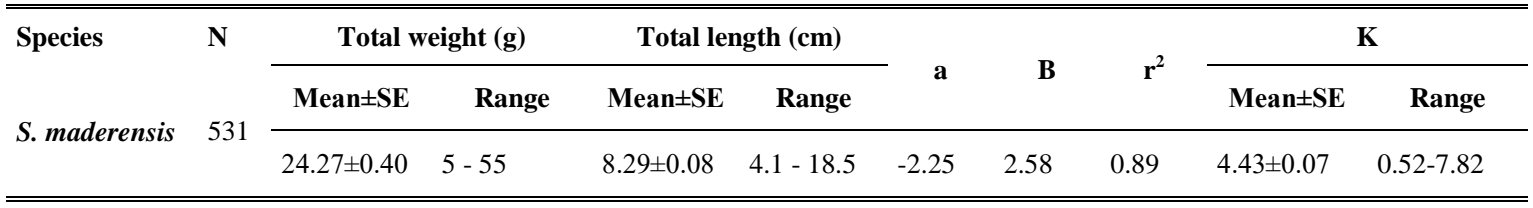

\section{Growth parameters}

Parameters of von Bertalanffy's equations were estimated as shown in Table 2. Asymptotic length stood at $23.31 \mathrm{~cm}$, growth coefficient $(\mathrm{k})$ was estimated at 0.54 and age at zero length $\left(\mathrm{t}_{0}\right)$ stood at 0.03 year- $^{-1}$ in the restructured form of the length-frequency data is presented as output of ELEFAN I in Figure 4.

Table 2. Growth parameters of $S$. maderensis from Sombreiro River

\begin{tabular}{ll}
\hline \hline Von Bertalanffy's Growth parameters & ELEFAN-I \\
\hline Asymptotic length $(\mathrm{cm})$ & 23.21 \\
Growth coefficient $(\mathrm{k})$ & 0.54 \\
Age at zero length $\left(\mathrm{t}_{0}\right)(\mathrm{yr})$ & -0.03 \\
Growth Performance index $(\Phi)$ & 2.46 \\
\hline \hline
\end{tabular}

\section{Mortality parameters and exploitation ratio}

The mortality parameters and exploitation ratio are shown in Table 3.Total mortality $(\mathrm{Z})$ was found to be 2.74 year- $^{-}$. Fishing mortality was computed as 1.42 year- $^{-1}$ and Natural mortality was 1.32 at an annual average sea surface temperature of $29.7^{\circ}$ Figure 4 . The estimated fishing mortality $(\mathrm{Z}-\mathrm{M}=\mathrm{F})$ stood at 0.518 .

Table 3. Mortality parameters and exploitation ratio of S. maderensis from Sombreiro River

\begin{tabular}{ll}
\hline \hline Fishing mortality $(\mathrm{F})$ & 1.42 \\
Natural mortality $(\mathrm{M})$ & 1.32 \\
Total mortality $(\mathrm{Z})$ & $\mathbf{2 . 7 4}$ \\
Exploitation ratio $(\mathrm{E}=\mathrm{F} / \mathrm{Z})$ & 0.518 \\
\hline \hline
\end{tabular}


The length-based index of growth performance $\left(\varnothing^{\prime}\right.$ - phi prime) for $S$. maderensis was estimated at 2.46 (Table1 and Figure 2).

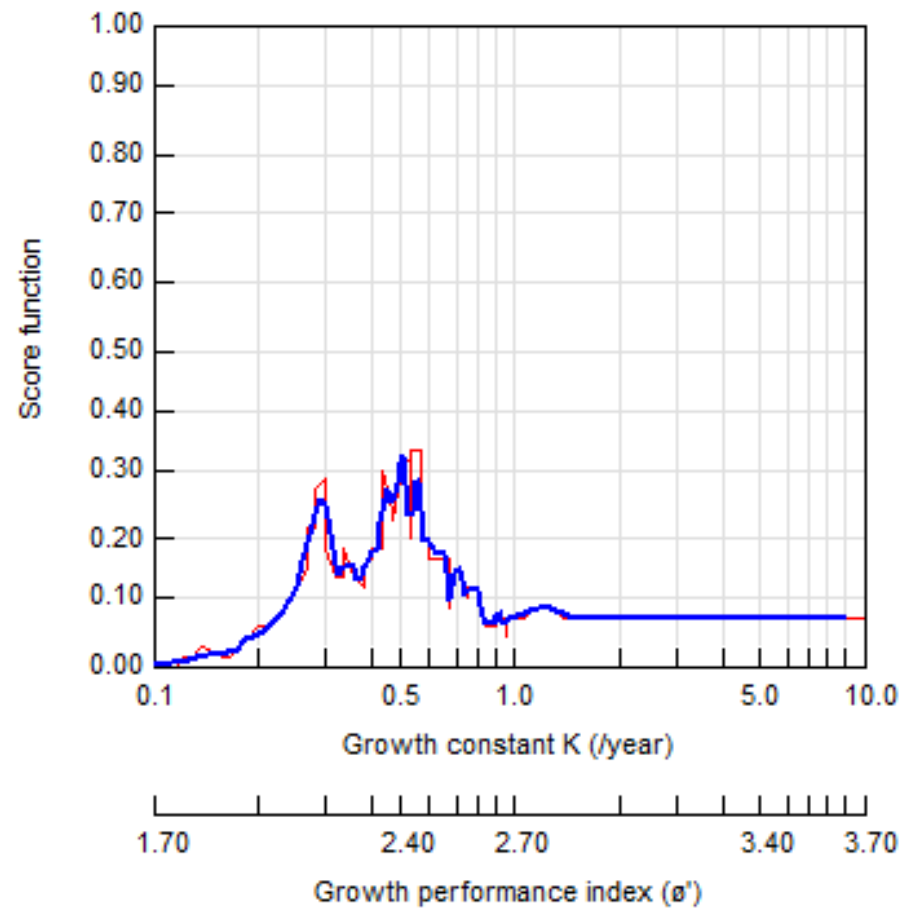

Figure 2. Growth Performance index of S. maderensis from Sombreiro River

\section{Recruitment patterns}

The recruitment patterns for $S$. maderensis is shown in Figure 3. Spawning capable individuals were recorded throughout the entire fishing period and the species showed year round recruitment patterns having two peak periods which occur in two nearly equal pulses. The minor peak during April and major peak during July.

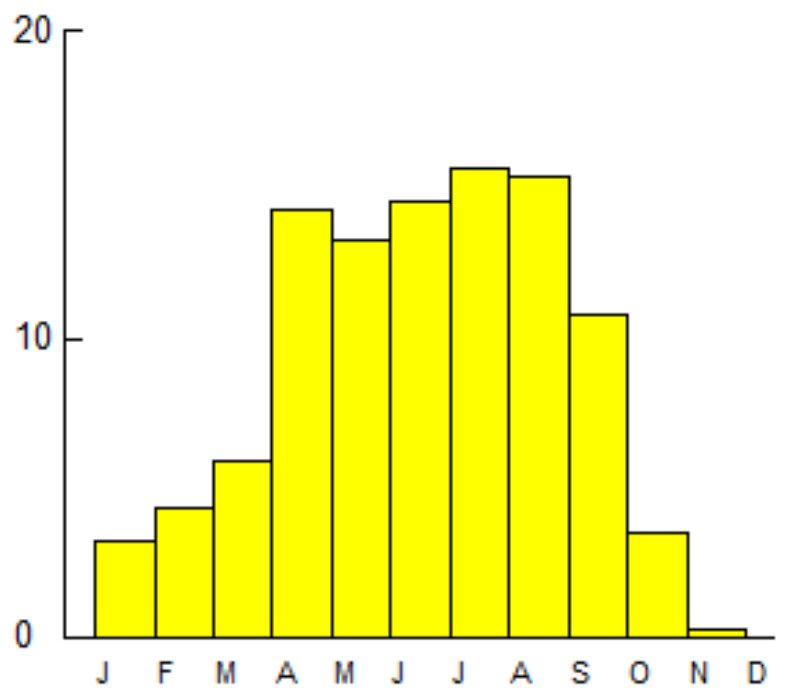

Figure 3. Recruitment patterns of $S$, maderensis from Sombreiro River 
Figure 4 below showed the restructured length frequency with superimposed growth curves with bimodal population structure, indicating probably the existence of six cohorts within the population.

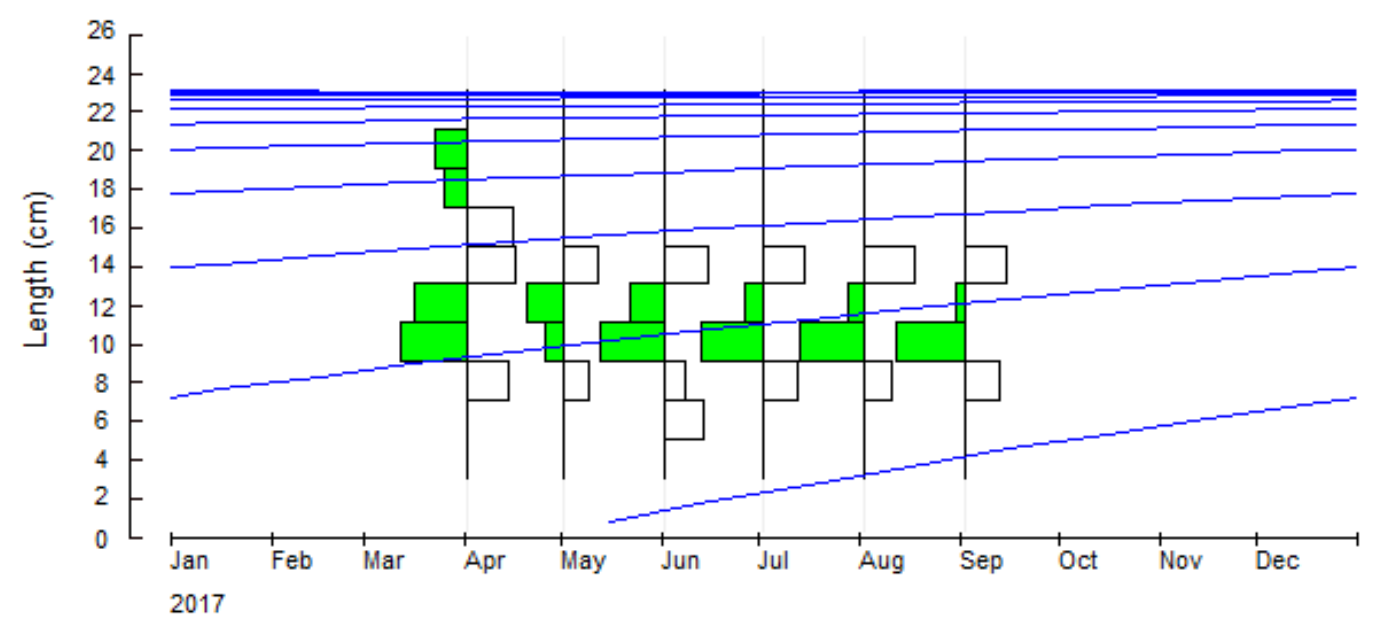

Figure 4. Length frequency distribution data and growth curve parameters using ELEFAN for S. maderensis from Sombreiro River

Figure 5 revealed the length at first capture $\mathrm{L}_{50}$ was $27.31 \mathrm{~cm}, \mathrm{~L}_{25}$ estimated at $14.88 \mathrm{~cm}$ and the length at which $75 \%$ fish are retained in the gear was estimated as $39.75 \mathrm{~cm}$.

\section{Probability of Capture}

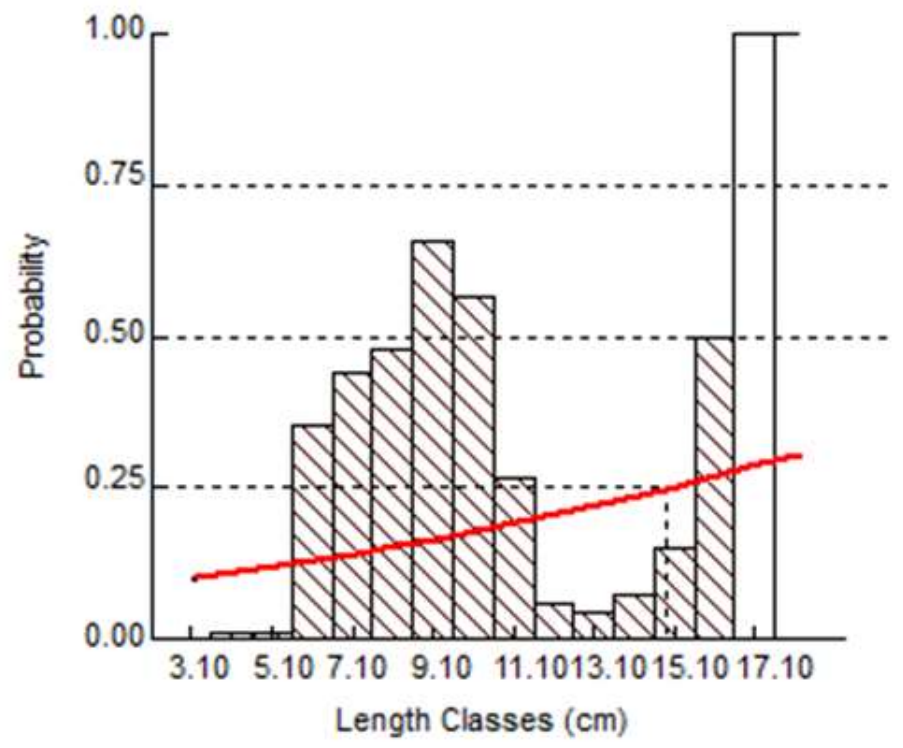

Figure 5. The probability capture curve showing the $\mathrm{L}_{25}, \mathrm{~L}_{50}$ and $\mathrm{L}_{75}$ of length converted catch curve 


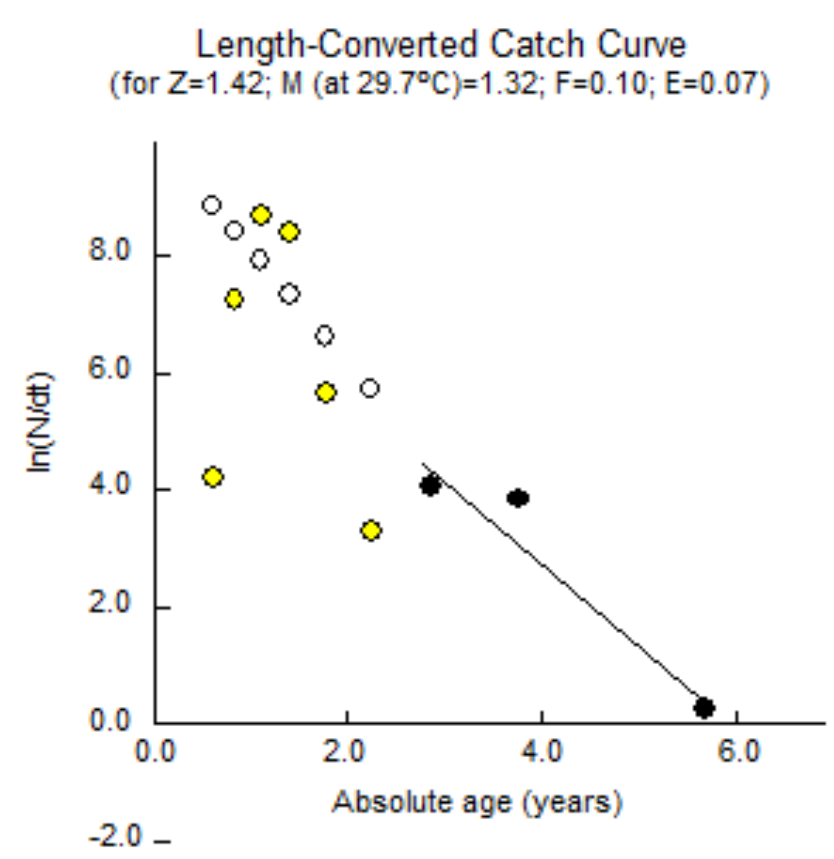

Figure 6. Length converted catch curve of S. maderensis using VBGF growth parameters

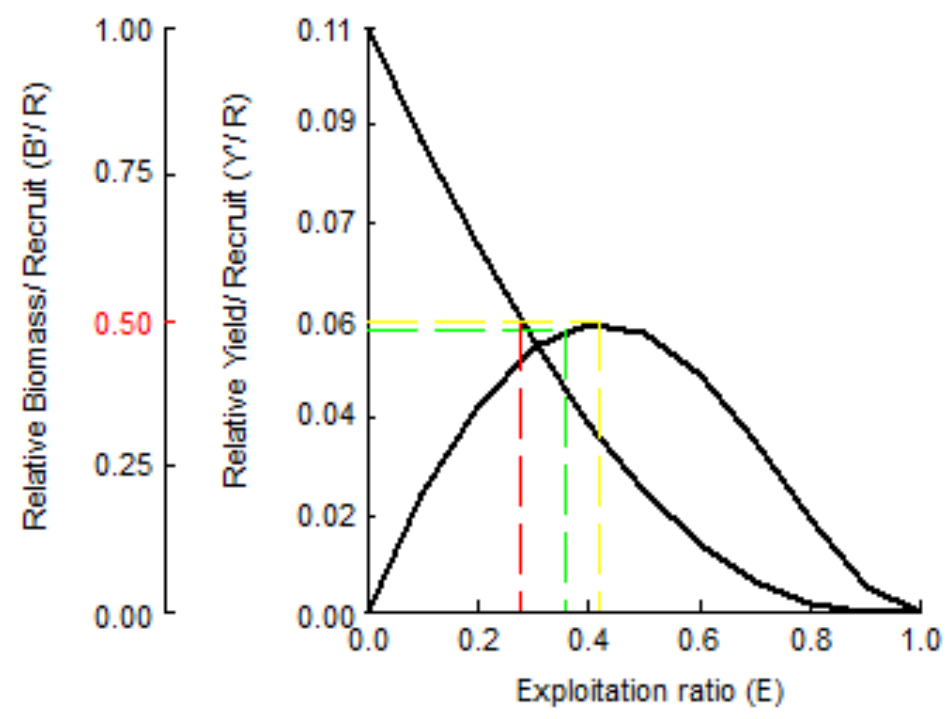

Figure 7. Relative yield per recruit and biomass per recruit curves of S. maderensis in Sombreiro River

\section{Stock status of using Beverten and Holt's relative $Y / R$ analysis}

The relative yield-per-recruit (Y/R) and relative biomass-per-recruit $(\mathrm{B} / \mathrm{R})$ analysis by the knifeedge selection method. The exploitation rate (Emax) that gives maximum relative yield-per-recruit was 0.421 . The exploitation rate at which marginal increase occurred in the relative yield-per-yield was $10 \%$ of its value at $\mathrm{E}=0$, whereas $\left(\mathrm{E}_{0.1}\right)$ was observed to be 0.355 (Figure 7). The exploitation rate $\left(\mathrm{E}_{0.5}\right)$ which corresponds to $50 \%$ of the virgin (that is., the unexploited stock) relative biomassper-recruit was estimated to be 0.278 . 


\section{DISCUSSION}

Estimation of the population size of a fish stock for the purpose of its rational exploitation often requires knowledge of these relationships (Le Cren, 1951). Values of the exponent ' $b$ ' provide information on fish growth. The values of length-weight regression coefficient "b" in this study was 2.58 negative allometric growth pattern ( $b>3$ ) meaning that the weight increase is made faster than the growth in length. This value is within the expected range of $2-4$ reported by Tesch (1971), and $2.5<\mathrm{b}$ $<3.5$ by Froese (2006). However, the negative allometric growth pattern obtained in this study for $S$. maderensis was in contrary with the positive allometric growth reported for this species in Nkoro River (Niger-Delta) (Abowei, 2009). The value of ' $b$ ' may be due to feeding, sex, state of maturity, metabolic activity and genetic nature (Wootton, 1990). The length-weight relationship provides means for finding out the condition factor which indicates the "Wellbeing of the fish". The condition factor was very high in this fish species, the values ranged from 3.04 - 4.43. This could be attributed to the length range of the sampled specimens. Salam et al. (2005) pointed out that 'K' remained constant with increasing in length and weight of fish.

In this study the values of asymptotic length $(\mathrm{L} \infty)$ and growth coefficient $(\mathrm{k})$ were calculated as $23.31 \mathrm{~cm}$, and 0.54 respectively. The results are in agreement with Beverton and Holt (1959) who pointed out that the two parameters of growth, asymptotic length and growth coefficient are inversely proportionally to each other. It implies that fishes with high $\mathrm{L} \infty$ should be with lower $\mathrm{K}$ values and those with lower L $\infty$ with higher $\mathrm{K}$ values. The estimated growth rate was within the range: 0.34 per year and 0.67 per year, suggesting that $S$. maderensis is an intermediate growing fish species, evinced by its lifespan of 7.51 years (Kienzle, 2005). On the other hand, the L $\infty$ value $(23.31 \mathrm{~cm})$ in this study was smaller than $37.5 \mathrm{~cm}$ reported by Marcus (1989) from coastal waters around Lagos, Nigeria, on the same species. The difference may be due to the ecological differences, feeding variability and most importantly fishing pressure.

Age at zero length $\left(\mathrm{t}_{0}\right)$ stood at -0.03 year- ${ }^{-1}$. Amponsah et al. (2018) reported the age at birth $\left(\mathrm{t}_{0}\right)$ for the same fish species at -0.284 year- ${ }^{1}$ from coastal waters of Ghana. It has been reported that there must be some differences between growth characteristics among localities as a result of diversity and availability of dietary items, hydrographical and climatic conditions (Bartulovic et al., 2004).

In this study the value of growth performance index of S. maderensis was found to be 2.46 . The result is lower than values reported for the same species by Amponsah et al., (2018) in coastal waters of Ghana and by Marcus (1989) in coastal waters around Lagos, Nigeria. The difference in values could be due to poor state of water quality in the study area as a result oil pollution and other human activities in and around the Sombreiro River. The value recorded in the current study was lower than recommended value for fishes in Africa. Baijot and Moreau (1997) estimated that the $\phi^{\prime}$ mean value for some important fishes in Africa have a range of 2.65 - 3.32, which they considered as low. According to Kalhoro et al. (2015) the higher value of growth performance index indicates that fish can grow faster and larger.

Total mortality $(\mathrm{Z})$ was found to be 2.74 year- $^{1}$, fishing mortality was computed as 1.42 year- $^{-1}$ and natural mortality stood at 1.32 . The total mortality $(\mathrm{Z})$ was slightly higher than the Hashem and Faltas (1982) estimated Z by 2.399 for S. maderensis in El-Mex. The high estimated Z in this study may indicate more pressure on the species that may be resulted from increasing in one, or both the components (M and $\left.\mathrm{F}^{\prime}\right)$ of $\mathrm{Z}$. Sardine is vulnerable to a wide variety of predators, including many recreationally and commercially important fish species such as Scomber japonicus (Rizkalla and Faltas, 1997). The fishing mortality was slightly higher than the natural mortality and exploitation rate estimated (E) at 0.52 showed that that the level of exploitation is already high and species may not be in a sustainable condition. The exploitation rate in this study was almost the same with 0.5 optimally exploited stock which shows that the stock of this species may be under the pressure and not in a safe condition. Coefficient of exploitation higher than 0.5 along with higher fishing mortality compared to natural mortality show the stock is under overfishing pressure (King, 2007).

The species showed year round recruitment patterns having two peak periods. The minor peak during April and major peak during July. Pauly (1982) reported that double recruitment pulses per year for tropical fish species and for short-lived species. Recruitment has been described as a yearround phenomenon for tropical fish and shrimps species (Weber, 1976). The results obtained by Diouf et al. (2010) show a continuous reproduction for $S$. maderensis throughout the year. 
In this work, the length at first capture $\mathrm{L}_{50}$ and $\mathrm{L}_{25}$ were $27.31 \mathrm{~cm}$ and $14.88 \mathrm{~cm}$ respectively. The length at which $75 \%$ fish are retained in the gear was estimated as $39.75 \mathrm{~cm}$.. The values in the current study were higher than those recorded in the coastal waters of Ghana for S. maderensis $\mathrm{L}_{25} \%, \mathrm{~L}_{50} \%$ and $\mathrm{L}_{75} \%$ were $4.40 \mathrm{~cm}, 5.30 \mathrm{~cm}$ and $6.12 \mathrm{~cm}$ respectively by (Amponsah et al., 2018) In Senegal, the work performed by Boely (1980) and (Levenez 1993) showed that the $\mathrm{L}_{50}$ in this area was $20 \mathrm{~cm}$.

The present level of exploitation rate $(\mathrm{E}=0.36)$ was close to the maximum allowable limit based on the yield-per-recruit calculation $\left(\mathrm{E}_{\max }=0.42\right)$ indicating that that the level of exploitation is already high.

\section{CONCLUSION}

The results reveal that the level of exploitation is already high for this species and to obtain the maximum sustainable yield, the present level of fishing effort should be reduced. The present results can serve as baseline data for species with no previous information regarding stock assessment and for comparisons in future studies of Nigerian inland water fishery.

\section{REFERENCES}

Abowei, J. F. N. (2009). The Abundance Condition Factor and Length-Weight Relationship of some Sardinella maderensis (Jenyms, 1842) from Nkoro River, Niger Delta, Nigeria. Advanced Journal of Food Science and Technology, 1, 65-70.

Adesulu, E. A., \& Sydenham D. H. J. (2007). The fresh water and fisheries of Nigeria. Macmillan Nigeria Publishers, Lagos, $397 \mathrm{pp}$.

Amponsah, S. K. K., Ofori-Danson, P. K., Nunoo, F. K. E., \& Ameyaw, G. A. (2018). Estimates of Population parameters of the Flat sardine, Sardinella maderensis (Lowe, 1838) in the coastal waters of Ghana. Greener Journal of Agriculture Sciences, 9 (1), 23-37.doi.org/10.15580/GJAS.2019.1.011719017

Baijot, E., \& Moreau, J. (1997). Biology and demographic status of the main fish species in the reservoirs of Burkina-Faso. In: Baijot, E., Moreau, J., Bouda, S. (Eds.), Hydro biological aspects of fisheries in Small Reservoirs in the Sahel Region. Technical Centre for the European Communities, Wageningen, the Netherlands, pp. 79-109.

Bartulovic, V., Glamuzina, B., Conides, A., Dulcic, J., Lucic, D., Njire, J., \& Kozul, V. (2004). Age, Growth, mortality and sex ratio of sand smelt, Atherina boyeri, Risso, 1810 (Pisces: Atherinidae) in the Estuary of the Mala Neretva River (Middle-Eastern Adriatic, Croatia). Journal of Applied Ichthyology, 20, 427-430.

Beverton, R. J. H., \& Holt, S. J. (1956). A review of methods for estimating mortality rates in fish populations, with special reference to sources of bias in catch sampling. Rapports et Proce`s-verbaux des Re'unions, Conseil.

Beverton, R. J. H., \& Holt, S. J. (1959). A review of the life spans, natural mortality, and their relation to growth and other physiological characteristics. In CIBA colloquium on Aging. (Wolstenholme G. E. W. and MO'Connor Eds) London, Churchill, 5,142-180

Boely, T. (1980). Etude du cycle sexuel de la sardinelle plate: Sardinella maderensis (Lowe, 1841) des cotes senegalaise. Cybium, 8, 77-88

de Graaf, G. J., Nunoo, F., Ofori Danson, P., Wiafe, G., Lamptey, E., \& Bannerman, P. (2015). International training course in fisheries statistics and data collection. FAO Fisheries and Aquaculture Circular No. 1091. Rome, FAO. 134 pp.

Diouf, P. S. (1996). The Fish Population of the estuarine environment of the African coast: The example of the estuary salinity of the Sine saloum. University of Montpellier II. Thesis and Documents No. 156. ORSTOM, Paris. 267

Diouf, K., Samb, B., \& Sylla, M. (2010). Contribution a la Connaissance de la Biologie des Sardinelles (Sardinella aurita et Sardinella maderensis) du Littoral Senegalais. In: Science et Amenagement des Petits Pelagiques. Symposium sur la Science et le Defi de l'Amenagement des Pecheries de petits Pelagiques sur les Stocks Partages en Afrique Nord-Occidentale, 11-14 Mars 2008, Casablanca, Maroc, FAO Comptes Rendus des Peches et de l'Aquaculture, No. 18, Dans Garcia, S., M. Tandstad and A.M. Caramelo (Eds.)., FAO., Rome, 39-56.

Ezekiel, E. N., Hart, A. I., \& Abowei, J. F. N. (2011).Benthic Macro- Fauna Composition and Abundance in Sombreiro River, Niger Delta, Nigeria. Research Journal of Applied Science and Engineering Technology, 3(4), 257-263

Froese, R. (2006). Cube law, condition factor and weight-length relationships: history, meta-analysis and recommendations. Journal of Applied Ichthyology, 22, 241-253

Froese, R., \& Pauly, D. (2017). FishBase. World Wide Web Electronic Publication, France 
Gaudant, J. (1991). Paleontology and history of clupeoid fishes. p. 32-44. In H. Hoestlandt (ed.) The freshwater fishes of Europe. Aula Verlag, Wiesbaden, Germany

Haddon, M. (2011). Modeling and Quantitative Methods in Fisheries. Chapman and Hall, CRC Press, London, 449 PP.

Hashem, M .T., \& Faltas, S. N. (1982). Fisheries investigation of the sardine gill net at El-Max Region, near Alexandria. Bulletin of Institution of Oceanography and Fisheries ARE 8 (2), 137-155.

Hoggarth, D. D., Abeyasekera, S., Arthur, R., Beddington, J. R., Burn, R. W., Halls, A. S., Kirkwood, G. P., McAllister, M., Medley, P., Mees, C. C., Pilling, G. M., Wakeford, R., \& Welcomme, R. L. (2006). Stock assessment and fishery management - A framework guide to the FMSP stock assessment tools". FAO Fisheries Technical Paper No. 487, Rome, Italy, 261 pp.

Kalhoro, M. A., Liu, Q., Valinassab, T., Waryani, B., Abbasi, A .R., \& Memom, K. H. (2015) Population Dynamics of Greater Lizardfish, Saurida tumbil From Pakistani Waters. Pakistan Journal of Zoology, 47 (4), 921-931

Kienzle, M. O. (2005). Estimation of the population parameters of the Von Bertalanffy Growth Function for the main commercial species of the North Sea. Fisheries Research Services Internal Report pp. 34.

King, M. (2007). Fisheries biology and assessment and management. Fishing News Press, 340p.

Le Cren, E. D. (1951). The length-weight relationship and seasonal cycle in the gonad weight and condition in the perch (Perca fluviatilis). Journal of Animal Ecology, 20, 201-219

Levenez, J. J. (1993). Synthese Bibliographique des Connaissances sur la Biologie de Quelques Especes de Poissons Concernant le Symposium. In: L'Evaluation des Ressources Exploitables par la Peche Artisanale Senegalaise, Barry-Gerard, M., T. Diouf, A. Fontenau (Eds.). ORSTOM., France, pp: 121-141.

Marcus, O. (1989). Breeding, age and growth in Sardinella maderensis (Lowe 1839) Pisces: Clupeidae from coastal waters around Lagos, Nigeria. Nigerian Journal of Sciences, 23 (1-2), 1-5,

National Bureau of Statistics (NBS) 2017. Nigerian's fish production 2010-2015.

Nduaguba, D.C. (1983). Utilization of remote sensing data for mapping aquatic ecosystems of the Nigerian coastal areas. RSC Series 15, FAO, Rome.

Paul, D. (1980). A selection of simple methods for the assessment of tropical Fish stocks. FAO. Fisheries Circular 729, FAO, Rome

Pauly, D (1982). Studying single-species dynamics in a tropical multi-species context. In: Pauly D, Murphy GI (Eds). Theory and management of tropical fisheries. ICLARM Fishbyte,3, 13-14.

Pauly, D. (1983). Some Simple Methods for Assessment of Tropical Fish Stocks. Fisheries Technical Paper, 234, FAO, $52 \mathrm{PP}$

Pauly, D., \& Munro, J. I. (1984). Once More on the Comparison of Growth in Fish and Invertebrates. Fish Byte, 2, 21-23

Pauly, D., \& Caddy, J. F. (1985). A modification of Bhattacharya's method for the analysis of mixtures of normal distributions, FAO Fisheries Circular, 781, FAO, Rome, Italy, 16 pp.

Pauly, D., \& Soriano, M. L. (1986). Some practical extensions to Beverton and Holt's relative yield per-recruit model. In: JL. Maclean, LB. Dizon, LV. Hosillos. (Eds.) The First Asian Fisheries Forum, Asian Fisheries Society, Manila, Philippines, 1986, pp. 491-496.

Riede, K. (2004). Global register of migratory species - from global to regional scales. Final Report 'of the R\&D-Projekt 80805 081. Federal Agency for Nature Conservation, Bonn, Germany. 329 p.

Rizkalla, S. I., \& Falats, S. N. (1997). Feeding habits of chub mackerel (Scomber japonicus) in Egyptian Mediterranean waters. Journal of King Abdulaziz Marine Sciences, 8, 127-136.

Salam, A., Naeem, M., \& Kauser, S. (2005). Weight length relationship and Condition factor relationship of fresh water wild Puntius chola from Islambad, Pakistan. Pakistan Journal of Biological Sciences, 8 (8), 1112-1114.

Schneider, W. (1990). FAO species identification sheets for fishery purposes. Field guide to the commercial marine resources of the Gulf of Guinea. Prepared and published with the support of the FAO Regional Office for Africa.Rome, FAO. 1990. 268 p.

Ssentongo G. W, Ajayi, T. O., \& Ukpe, E. T. (1983). Report on a resource appraisal of the artisanal and in shore fisheries of Nigeria. FAO, Rome FI: DP/NIR/77/001 p.43

Tesch, F. W. (1971). Age and growth. In: Methods for assessment of fish production in fresh waters. W. E. Ricker (Ed.) Blackwell Scientific Publications, Oxford, pp. 98-130

Tous, P., Sidibé, A., Mbye, E., de Morais, L., Camara, K., Munroe, T., Adeofe, T.A., Camara, Y.H., Djiman, R., Sagna, A., et al. (2015)."Sardinella maderensis". The IUCN Red List of Threatened Species. IUCN. 2015: e.T198582A15543624. doi:10.2305/IUCN.UK.2015-4.RLTS.T198582A15543624.en. Retrieved 16 June 2018

Weber, W. (1976). The influence of hydrographic factors on the spawning time of tropical fish. In: Tiews K (ed), Fisheries resources and their management in Southeast Asia: pp. 269-281. 
Whitehead, P. J. P. (1985). FAO Species Catalogue. Vol. 7. Clupeoid fishes of the world (suborder Clupeoidei). An annotated and illustrated catalogue of the herrings, sardines, pilchards, sprats, shads, anchovies and wolf-herrings. FAO Fish. Synop. 125 (7/1), 1-303. Rome.

Wootton, R. J. (1990). Ecology of Teleost Fishes. 1st Edn., Chapman and Hall, London, UK., ISBN-13: 9780412317200, Pages: 404. 